\title{
Not all viruses in nature are human enemies: a perspective on aquatic virus ecology in Brazil
}

Nem todos os vírus na natureza são inimigos humanos: uma perspectiva sobre a ecologia dos vírus aquáticos no Brasil

Pedro Ciarlini Junger ${ }^{1 *}$ (D), Rafael Marques Almeida ${ }^{2}$ (D), Raquel Mendonça ${ }^{3}$ (D),

Vinicius Fortes Farjalla ${ }^{4}$ (D), Rossana Correa Netto de Melo $^{5}$ (D), Fábio Roland ${ }^{3}$ (D) and

Nathan Barros ${ }^{3}$

${ }^{1}$ Laboratório de Biodiversidade e Processos Microbianos - LMPB, Departamento de Hidrobiologia, Centro de Ciências Biológicas e da Saúde, Universidade Federal de São Carlos - UFSCar, Rodovia Washington Luís, CEP 13565-905, São Carlos, SP, Brasil

${ }^{2}$ Department of Ecology and Evolutionary Biology, Cornell University, 14853, Ithaca, NY, USA

${ }^{3}$ Laboratório de Ecologia Aquática, Departamento de Biologia, Instituto de Ciências Biológicas, Universidade Federal de Juiz de Fora - UFJF, Rua José Lourenço Kelmer, CEP 36036-900, Juiz de Fora, MG, Brasil

${ }^{4}$ Departamento de Ecologia, Instituto de Biologia, Universidade Federal do Rio de Janeiro - UFRJ, Av. Carlos Chagas Filho, 373, CEP 21941-590, Rio de Janeiro, RJ, Brasil

${ }_{5}^{5}$ Laboratório de Biologia Celular, Departamento de Biologia, Instituto de Ciências Biológicas, Universidade Federal de Juiz de Fora - UFJF, Rua José Lourenço Kelmer, CEP 36036-900, Juiz de Fora, MG, Brasil

*e-mail: pedro.junger@gmail.com

Cite as: Junger, P.C et al. Not all viruses in nature are human enemies: a perspective on aquatic virus ecology in Brazil. Acta Limnologica Brasiliensia, 2020, vol. 32, e105.

Abstract: Viruses cause various diseases in humans through vector-borne (e.g., Zika and dengue fever), airborne (e.g., measles) and water-borne (e.g., hepatitis) transmission, as well as direct physical contact (e.g., AIDS and herpes). Recently, the new coronavirus (SARS-CoV-2) pandemic has triggered the greatest global health crisis in a century. However, not all viruses in nature are human enemies. A vast body of literature indicates that viral infection is vital for ecosystem functioning by affecting nutrient cycling, controlling species growth and enhancing biodiversity. Here we provide a perspective on the ecological role of viruses in nature, with special focus on Brazilian aquatic ecosystems.

Keywords: viral ecology; virioplankton; microorganisms; aquatic ecosystems; tropics.

Resumo: Os vírus causam doenças em humanos por meio de vetores (e.g., Zika e dengue), pelo ar (e.g., sarampo), pela água (e.g., hepatite) e por contato físico direto (e.g., AIDS e herpes). Recentemente, a pandemia do novo coronavírus (SARS-CoV-2) ocasionou a maior crise sanitária do século. No entanto, nem todos os vírus na natureza são inimigos humanos. Diversos estudos têm mostrado que a infecção viral é fundamental para o funcionamento de ecossistemas, afetando o ciclo de nutrientes, controlando o crescimento de algumas espécies e aumentando a biodiversidade. Esta mini-revisão apresenta uma perspectiva do papel ecológico dos vírus na natureza, com foco em ambientes aquáticos Brasileiros.

Palavras-chave: ecologia viral; virioplâncton; microrganismos; ecossistemas aquáticos; trópicos. 


\section{A Hidden Microscopic World}

The basis of food webs in aquatic ecosystems is formed by microorganisms invisible to the naked eye. These microbes interact in numerous and complex ways that are key for trophic relationships. The energetic principle of aquatic ecosystem functioning relies largely on the photosynthetic process, by which autotrophic organisms (e.g., algae and aquatic macrophytes) use light to convert carbon dioxide $\left(\mathrm{CO}_{2}\right)$ into organic matter, releasing oxygen to the environment. Autotrophic organisms (primary producers) are consumed by primary consumers that can be microscopic (e.g., protozoa, rotifers, and small crustaceans) or macroscopic (e.g., mollusks, large crustaceans and small fish). Throughout this process energy is successively transferred up to organisms at higher trophic levels.

Microscopic non-primary producers such as bacteria and viruses also play a key role in transferring energy to higher trophic levels. Bacteria are vital to the machinery that keeps food webs functioning in aquatic ecosystems (Cotner $\&$ Biddanda, 2002). First, they recycle organic matter and nutrients, which are used by primary producers. Second, bacteria can be food themselves for consumers, instead of primary producers (Hall Junior \& Meyer, 1998). This alternative pathway of carbon and energy flow in aquatic ecosystems is commonly known as "microbial loop" (Azam et al., 1983). Until the end of the 1980s, it was thought that viruses occurred in low densities in ecosystems and that their ecological role was insignificant. In the early 1990s, this paradigm was shifted with the development of new microscopy techniques used for counting viral particles (Bergh et al., 1989). Viruses have also been counted with flow cytometry
(Brussaard, 2004), a technique that measures the physical and chemical characteristics of biological particles suspended in liquid. Currently, it is known that the density of viruses in lakes can be in the order of 10 billion viral particles for each liter of water (Knowles et al., 2016). This massive number of viral particles can be 10 to 100 times greater than the number of free bacterial cells in aquatic ecosystems, suggesting that whatever ecological role viruses play, it is likely to be significant at the ecosystem scale.

\section{What do Aquatic Viruses do?}

Viruses are microscopic infectious agents that generally measure between 20 and 200 nanometers (Figure 1) and have a simple structure: a singleor double-stranded DNA or RNA (retrovirus) surrounded by a protein capsule and, sometimes, a lipid layer (Sime-Ngando, 2014). Viruses have been phenotypically classified into two groups: tailed and non-tailed. Non-tailed viruses dominate (5090\%) natural aquatic samples (Brum et al., 2013). However, this classification is far from representing the massive genetic diversity of viruses - the largest on Earth (Hambly \& Suttle, 2005). Virus taxonomy is very challenging because they lack a common ribosomal RNA nucleotide sequence (as all domains in the tree of life), but recent efforts with modern techniques have been revealing their great diversity (Gorbalenya et al., 2020).

Viruses do not breathe, do not move and do not grow, and they completely depend on their host for replication. Thus, viruses are considered biological entities that are mandatory intracellular parasites. Because viruses need a host to complete their life cycle, they can exist in two phases: extracellular and intracellular. In the first free extracellular

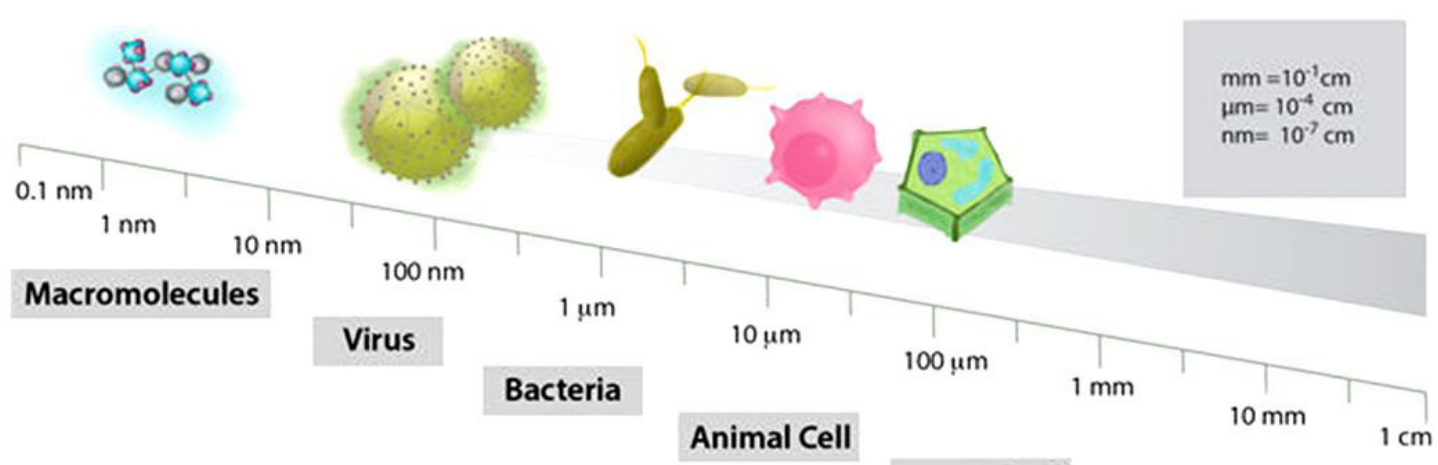

Vegetal Cell

Figure 1. Viruses are extremely small $(20-200 \mathrm{~nm})$, smaller than bacterial cells $(>1000 \mathrm{~nm})$, which in turn are smaller than animal and plant cells. $\mathrm{nm}=$ nanometer; $\mu \mathrm{m}=$ micrometer; $\mathrm{cm}=$ centimeter. Adapted from Melo (2018), with permission. 
phase, when they are called virions, they rely on random encounters with their hosts to introduce their genetic material into them (Willey et al., 2014). When the infection of the host cell occurs, the second phase of the virus life cycle begins and a variety of replication strategies can take place (Figure 2).

In the lytic cycle, viruses multiply inside the host cell, break the cell membrane (or wall), and new viruses return to the environment to infect other cells (Figure 2). With cell disruption, organic compounds, which are potentially used by other organisms, are released into the environment. In the lysogenic cycle, viruses infect the host cell, but as cell defenses are activated, the infection does not evolve and the virus genome is attached as a prophage in the host cell genome. These prophages are replicated alongside host cells replication until favorable conditions (e.g. weakened cell defenses) lead the viruses to shift from lysogenic to lytic cycle (Weinbauer \& Suttle, 1996). In the chronic infections, which are rare in virus-infected bacteria, viruses do not cause the host lysis while using their cell apparatus, but they constantly release progeny phage particles by budding or extrusion (Figure 2), thereby impacting the host fitness.
Viruses can infect aquatic microorganisms of all three domains: Eukarya, Archaea and Bacteria, as well as other (giant) viruses (Sime-Ngando, 2014). But the most common viral hosts in aquatic ecosystems are bacteria, which are essential players in ecosystem functioning (Sime-Ngando, 2014). Therefore, viruses that infect bacteria, also known as bacteriophages (Figure 3), are a good example for understanding why these tiny particles are so important for ecosystem functioning. After using the bacterial cellular apparatus for their replication in the lytic cycle, viruses burst the cell, releasing numerous new viruses for new host infections (Figure 2).

With the rupture of the cell wall, there is a release of all cell content that was previously in the cytoplasm of the bacteria. Cytoplasm is largely formed by compounds rich in carbon, nitrogen and phosphorus, which are essential, limiting elements for aquatic life. The release of these compounds diverts nutrients and organic material from higher trophic levels back to the water column (Bratbak et al., 1992), thus making them available to the base of the trophic web (primary producers and other bacteria) in a readily usable state. This

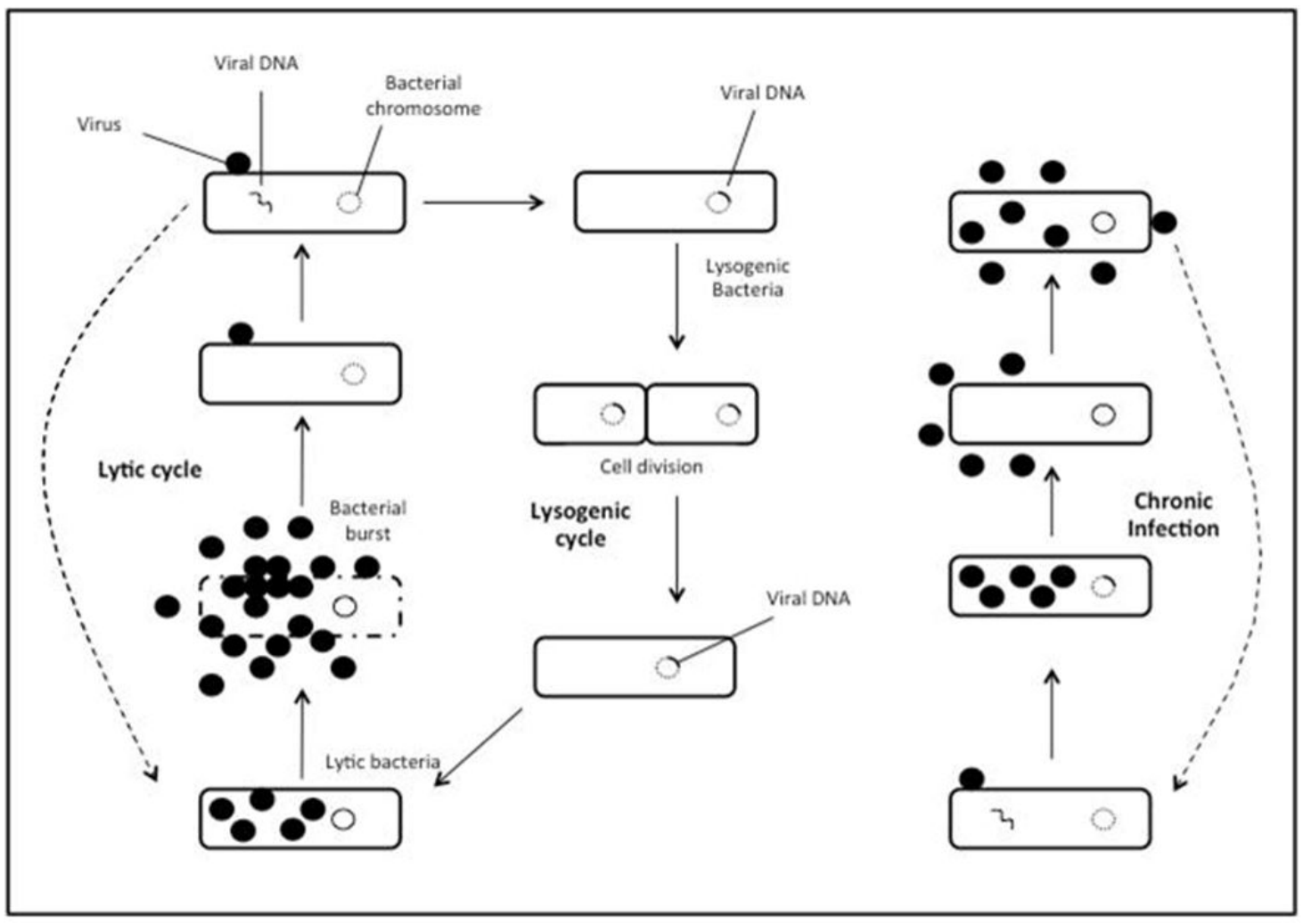

Figure 2. Simplified illustration of the three main virus replication strategies: lytic cycle, lysogenic cycle and chronic infection. 


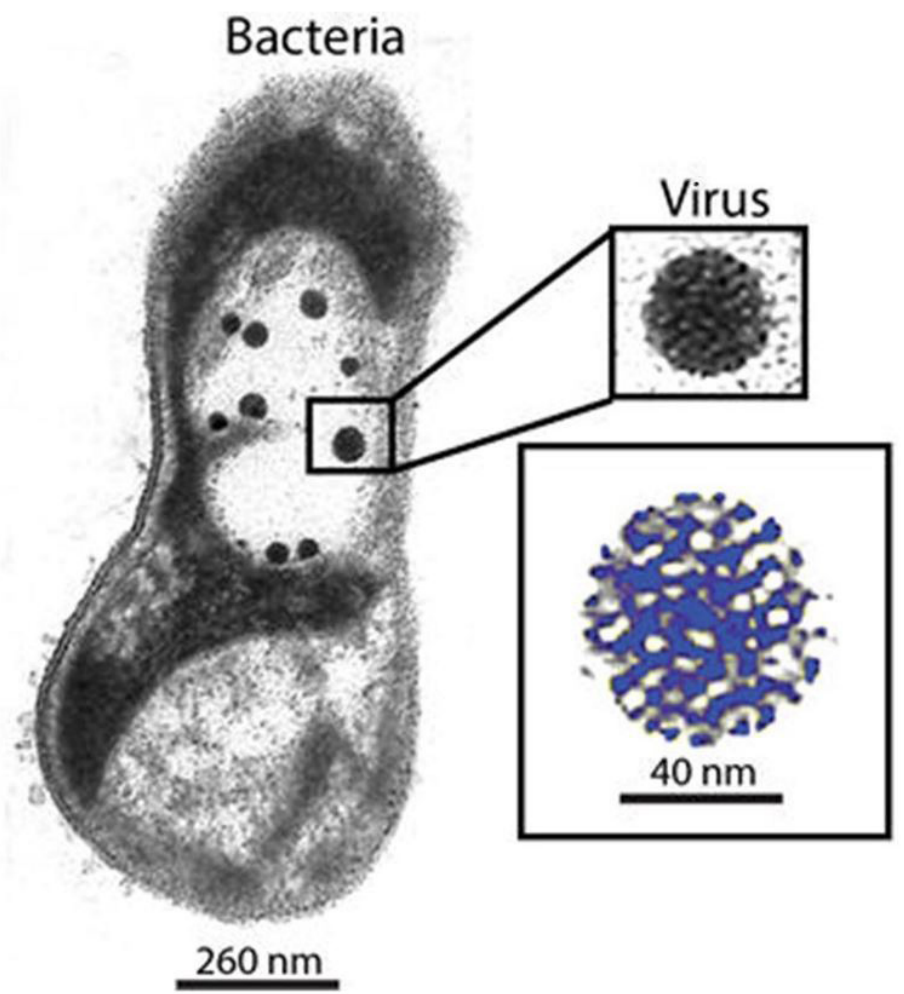

Figure 3. Image of an aquatic ecosystem bacterium infected with viruses, observed by transmission electron microscopy. The black "dots" indicate the presence of non-tailed bacteriophages in the bacterial cytoplasm. The boxed area shows a zoomed-in view of the structure of the viral protein capsule (capsid), composed of several repetitive morphological units (highlighted in blue). Image reproduced from Barros et al. (2010), with permission.

"short circuit" caused by viral infection is known in the scientific literature as the "viral loop" (Figure 4).

Viruses are important in controlling populations in aquatic ecosystems. In the same way that viruses such as SARS-CoV-2 drastically affect human population dynamics (from an ecological, not a public health standpoint), they can also control the growth of populations inhabiting aquatic ecosystems. For instance, on average $10 \%$ of algae mortality and $40 \%$ of bacterial mortality are caused by viral infection (Suttle, 2005). Moreover, viral infection potentially promotes the alternation between dominant species within a bacterial community (Pradeep Ram et al., 2016). When a dominant species is attacked by a virus, its density decreases, allowing for other species to thrive. Furthermore, viruses are important drivers of microbial evolution, as they are able to transfer genetic material between their hosts through transduction - a process in which a virus injects part of the genetic material of a host (donor) into a second host (recipient), which incorporates these genes into its own genetic material and, when multiplied, generates a lineage with new genetic characteristics. This type of lateral gene transfer has been demonstrated to take place in aquatic ecosystems at very high rates (Koonin \& Wolf, 2008).

Viruses can prevent the development of harmful algal blooms by limiting the algal population density (Baudoux \& Brussaard, 2005; Gastrich et al., 2004). Algal blooms occur when the algae find ideal growth conditions with high nutrient $(\mathrm{N}$ and $\mathrm{P}$ ) concentrations originated from natural or anthropogenic sources such as sewage and agricultural activity. Eutrophication has intensified algal blooms worldwide, representing a risk to aquatic biota and even human health, since some cyanobacteria can produce toxins. This viral control over dominant species of both bacteria and algae (known as the "killing the winner" hypothesis) may increase diversity and represents another important ecological function performed by viruses in ecosystems (Thingstad \& Lignell, 1997).

\section{The Understanding of Virus Ecology in Brazilian Aquatic Ecosystems}

Most of the advancements in understanding the ecological role of viruses in aquatic ecosystems come from studies in temperate systems. The viral- 


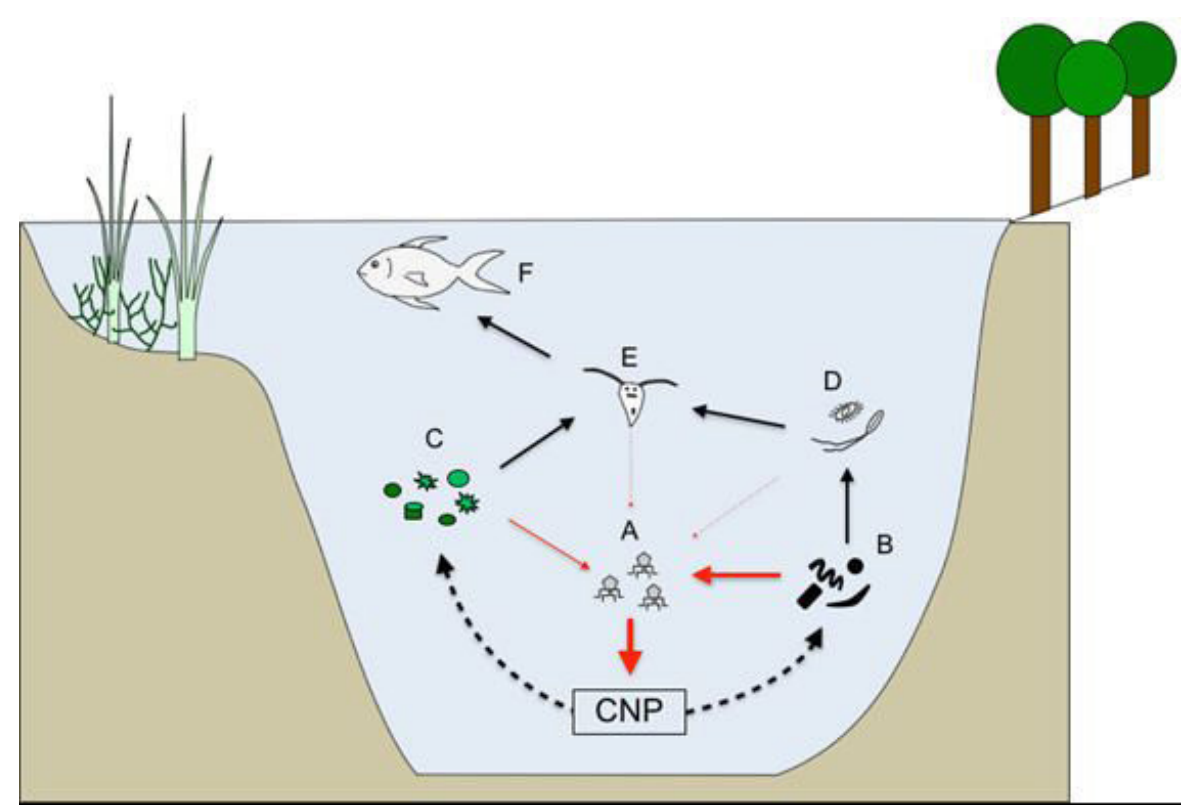

Figure 4. Illustration of the effects of the "viral loop" on aquatic food webs. Viruses (A) break host cells, which are often unicellular organisms such as bacteria (B) and phytoplankton (C), thereby releasing nutrients (carbon, nitrogen and phosphorus; CNP) into the water. In this way, viruses divert the amount of carbon that would reach higher trophic levels, such as microzooplankton (flagellates and ciliates - D), macrozooplankton (rotifers, cladocerans and copepods - E) and predators (e.g., fish - F), and release them back to the base of aquatic food webs (B and C). The black arrows indicate the regular flow of carbon in aquatic food webs, whereas the red arrows indicate the flows mediated by viruses. The width of the red arrows roughly represents the magnitude of these flows based on the relative abundance and biomass of these organisms usually found in aquatic ecosystems. Note that this is a theoretical picture and the width of the arrows may change between specific ecosystems. Figure adapted from Farjalla et al. (2011).

mediated ecosystem responses may depend on several factors such as water residence time, organic matter input, physical patterns (temperature, mixing regime, incident radiation) and biodiversity patterns. Hence, tropical aquatic ecosystems offer wide and still unexplored avenues for scientific investigation. Tropical environments have several distinct environmental characteristics when compared to temperate ones. The tropical singularity is strongly related to the highest incident solar irradiation, biomass variability, species richness and connectivity between lentic (ponds, lakes, and reservoirs) and lotic systems (streams and rivers). This systemic complexity regulates bacterial and algae abundances, metabolism and diversity, which in turn should affect the density, infection rates and population control by aquatic viruses.

Studies on virus ecology in Brazilian aquatic ecosystems are still scarce. The few studies available have been conducted in tropical ecosystems which were previously unexplored in terms of virus ecology (Figure 5). For instance, a study conducted in tropical coastal lagoons has shown that, among many environmental factors, salinity is the strongest environmental filter on virus, with a strong positive correlation between salinity and virus abundance (Junger et al., 2018). This investigation has also estimated a mean virus production of $13 \pm 14 \times 10^{7}$ virus-like particles (VLPs) $\mathrm{ml}^{-1} \mathrm{~h}^{-1}$, which is a rate 1-2 orders of magnitude higher than in temperate lakes. Besides, virus-mediated dissolved organic carbon release from bacterial cells represented $35-550 \%$ of the bacterial production, suggesting a relevant role of viruses in element cycling. Another study shows that viral biomass strongly correlates with both bacterial and phytoplankton biomasses in the Guanabara Bay (Cabral et al., 2017). Furthermore, two studies have shown strong positive relationships between virus and bacterial counts in Amazonian aquatic ecosystems (Barros et al., 2010; Almeida et al., 2015). Altogether, these studies have found that there is a strong correlation between virus and bacterial abundances (Figure 5), which is in line with findings across temperate and polar ecosystems (Knowles et al., 2016). This indicates that viruses are controlled by bacteria, but on the other hand they also regulate bacterial populations through cell lysis. This is corroborated by images obtained through transmission electron microscopy showing that about $30 \%$ of Amazonian aquatic bacteria are 


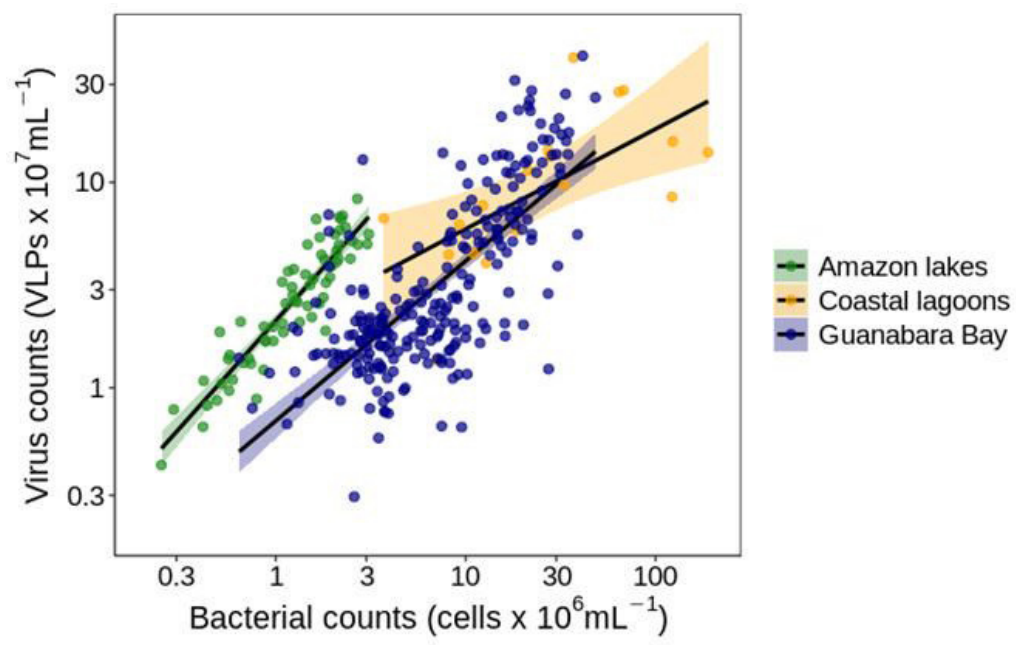

Figure 5. Regression between viruses and bacterial counts from water samples collected in Brazilian aquatic ecosystems. The strong positive relationships (Amazon lakes: $\mathrm{n}=66, \mathrm{r}^{2}=0.84, \mathrm{p}<0.01$; Coastal lagoons: $\mathrm{n}=18, \mathrm{r}^{2}=0.39$; $\mathrm{p}<0.01$; Guanabara Bay: $\mathrm{n}=246, \mathrm{r}^{2}=0.53$; $\left.\mathrm{p}<0.01\right)$ indicate that high bacterial abundances are generally followed by a greater number of viral particles. The literature data were obtained from Barros et al. (2010) (Amazon lakes), Almeida et al. (2015) (Amazon lakes), Cabral et al. (2017) (Guanabara Bay) and Junger et al. (2018) (coastal lagoons in the state of Rio de Janeiro).

on average infected with 10 viral particles per cell section (Barros et al., 2010; Figure 3). An impact on $30 \%$ of the bacterial community represents an important control on this community, often in a similar order of magnitude of other controlling processes such as grazing pressure (Fuhrman \& Noble, 1995).

Viruses can be classified phenotypically through direct observation of their forms with transmission electron microscopy, or phylogenetically through molecular evaluation of their genomes. Modern molecular approaches have lately revealed the genetic diversity of uncultured viral communities from marine (Gregory et al., 2019) and freshwater ecosystems (Kavagutti et al., 2019). As far as we know, there has been only one study investigating the virioplankton diversity in Brazilian inland waters (Silva et al., 2017). In this metagenomic study, the authors have shown a discontinuity in virioplankton assemblages from the lower Amazon river to its large plume on the South Atlantic Ocean (Silva et al., 2017). This suggests that environmental factors shape the spatial structure of virioplankton communities in tropical aquatic ecosystems. The highly diverse Brazilian inland waters represent good opportunities for discovering new freshwater viruses through molecular approaches, but very little has been explored so far.

Finally, even though aquatic sediments are known to have high viral activity and abundance, reaching from $10^{7}$ to $10^{10} \mathrm{VLPs} \mathrm{g}^{-1}$ of dry aquatic sediments (Danovaro et al., 2008), we do not know of any study investigating viriobenthos abundance, activity or diversity in Brazilian aquatic ecosystems.

\section{Virus-bacteria Vulnerability to Environmental Changes: an Example from the World's Largest Watershed}

The large temporal water level fluctuation seems to regulate viral and bacterial communities in Amazonian floodplain lakes (Barros et al., 2010). The typical water level variation of Amazonian environments promotes seasonal flood pulses that increase river levels by many meters, thereby inundating adjacent forests and lakes (Junk et al., 1989). In addition, when the level of the Amazon River is high it blocks the waters of its tributaries for tens of kilometers, causing a "backwater effect". Both the flood pulse and the backwater effect promote changes in the bacterioplankton communities composition of Amazonian floodplain lakes (Melo et al., 2019) and, in turn, should also shift virioplankton community assembly. Bacterial and virus abundances decrease during floods (Barros et al., 2010), especially in lakes which are most affected by the backwater effect (Almeida et al., 2015). This pattern is observed probably for two reasons: first, the quantity and quality of organic carbon decreases due to the greater entry of material from terrestrial vegetation, which is more resistant 
to decomposition; second, the great amount of water has a large dilution effect. The relationship between viruses and hydrodynamics in the Amazon suggests that viral communities may be susceptible to projected changes in the frequency and intensity of rainfall, which may modify flood regimes.

\section{Conclusion}

The fact that viruses infect and promote devastating diseases in species with abundant populations can be problematic, especially from a human health perspective. But viruses also perform essential ecological functions for the maintenance of biodiversity and the cycling of fundamental elements in the biosphere. The examples from Brazilian waters that we present here provide an indication of the importance of viruses in tropical aquatic food webs. Viruses are abundant in tropical aquatic ecosystems and are positively correlated with their main hosts (bacteria and phytoplankton). In addition to being abundant, viruses display high production rates that can greatly impact aquatic food webs and element cycling. However, there are still many gaps in our understanding of virus ecology in Brazilian and tropical waters in general. For instance, very little is known about virus activity and diversity, in part due to methodological and budget constraints. Additionally, viruses have not been studied in sediments, which are carbon hotspots and usually display high virus abundance. Besides expanding virus abundance counts in water and sediments from Brazilian aquatic ecosystems, future virus ecology studies could use metagenomic approaches to enhance our knowledge on viral diversity, especially from diverse freshwater ecosystems that represent potentially important places for new discoveries.

\section{Acknowledgements}

PCJ is grateful to the Fundação de Amparo à Pesquisa do Estado de Sáo Paulo - FAPESP for his PhD scholarship (grant 2017/26786-1).

\section{References}

ALMEIDA, R.M., ROLAND, F., CARDOSO, S.J., FARJALLA, V.F., BOZELLI, R.L. and BARROS, N.O. Viruses and bacteria in floodplain lakes along a major Amazon tributary respond to distance to the Amazon River. Frontiers in Microbiology, 2015, 6, 158. http://dx.doi.org/10.3389/fmicb.2015.00158. PMid:25788895.

AZAM, F., FENCHEL, T., FIELD, J.G., GRAY, J.S., MEYER-REIL, L.A. and THINGSTAD, F. The ecological role of water-column microbes in the Sea. Marine Ecology Progress Series, 1983, 10, 257-263. http://dx.doi.org/10.3354/meps010257.

BARROS, N., FARJALLA, V.F., SOARES, M.C., MELO, R.C.N. and ROLAND, F. Virus-bacterium coupling driven by both turbidity and hydrodynamics in an Amazonian floodplain lake. Applied and Environmental Microbiology, 2010, 76(21), 7194 7201. http://dx.doi.org/10.1128/AEM.01161-10. PMid:20833790.

BAUDOUX, A.-C. and BRUSSAARD, C.P.D. Characterization of different viruses infecting the marine harmful algal bloom species Phaeocystis globosa. Virology, 2005, 341(1), 80-90. http://dx.doi. org/10.1016/j.virol.2005.07.002. PMid:16081120.

BERGH, O., BØRSHEIM, K.Y., BRATBAK, G. and HELDAL, M. High abundance of viruses found in aquatic environments. Nature, 1989, 340(6233), 467-468. http://dx.doi.org/10.1038/340467a0. PMid:2755508.

BRATBAK, G., HELDAL, M., THINGSTAD, T.F., RIEMANN, B. and HASLUND, O.H. Incorporation of viruses into the budget of microbial C-transfer: a first approach. Marine Ecology Progress Series, 1992, 83(2-3), 273-280. http://dx.doi. org/10.3354/meps083273.

BRUM, J.R., SCHENCK, R.O. and SULLIVAN, M.B. Global morphological analysis of marine viruses shows minimal regional variation and dominance of non-tailed viruses. The ISME Journal, 2013, 7(9), 1738-1751. http://dx.doi.org/10.1038/ ismej.2013.67. PMid:23635867.

BRUSSAARD, C.P.D. Optimization of procedures for counting viruses by flow cytometry. Applied and Environmental Microbiology, 2004, 70(3), 15061513. http://dx.doi.org/10.1128/AEM.70.3.15061513.2004. PMid:15006772.

CABRAL, A.S., LESSA, M.M., JUNGER, P.C., THOMPSON, F.L. and PARANHOS, R. Virioplankton dynamics are related to eutrophication levels in a tropical urbanized bay. PLoS One, 2017., 12(3), e0174653. http://dx.doi.org/10.1371/journal. pone. 0174653 .

COTNER, J.B. and BIDDANDA, B.A. Small players, large role: microbial influence on biogeochemical processes in pelagic aquatic ecosystems. Ecosystems, 2002, 5(2), 105-121. http://dx.doi.org/10.1007/ s10021-001-0059-3.

DANOVARO, R., CORINALDESI, C., FILIPPINI, M., FISCHER, U.R., GESSNER, M.O., JACQUET, S., MAGAGNINI, M. and VELIMIROV, B. Viriobenthos in freshwater and marine sediments: a review. Freshwater Biology, 2008, 53(6), 1186-1213. http://dx.doi.org/10.1111/j.13652427.2008.01961.x. 
FARJALLA, V.F., AMADO, A.M. and ESTEVES, F.A. Bacterioplâncton. In: F.A. ESTEVES, ed. Fundamentos de limnologia. 3. ed. Rio de Janeiro: Interciência, 2011, pp. 355-373.

FUHRMAN, J.A. and NOBLE, R.T. Viruses and protists cause similar bacterial mortality in coastal seawater. Limnology and Oceanography, 1995, 40(7), 12361242. http://dx.doi.org/10.4319/lo.1995.40.7.1236.

GASTRICH, M.D., LEIGH-BELL, J.A., GOBLER, C.J., ROGER ANDERSON, O., WILHELM, S.W. and BRYAN, M. Viruses as potential regulators of regional brown tide blooms caused by the alga, Aureococcus anophagefferens. Estuaries, 2004, 27(1), 112-119. http://dx.doi.org/10.1007/BF02803565.

GORBALENYA, A.E., KRUPOVIC, M., MUSHEGIAN, A., KROPINSKI, A.M., SIDDELL, S.G., VARSANI, A., ADAMS, M.J., DAVISON, A.J., DUTILH, B.E., HARRACH, B., HARRISON, R.L., JUNGLEN, S., KING, A.M.Q., KNOWLES, N.J., LEFKOWITZ, E.J., NIBERT, M.L., RUBINO, L., SABANADZOVIC, S., SANFAÇON, H., SIMMONDS, P., WALKER, P.J., ZERBINI, F.M. and KUHN, J.H. The new scope of virus taxonomy: partitioning the virosphere into 15 hierarchical ranks. Nature Microbiology, 2020, 5(5), 668-674. http://dx.doi.org/10.1038/s41564020-0709-x. PMid:32341570.

GREGORY, A.C., ZAYED, A.A., CONCEIÇÃONETO, N., TEMPERTON, B., BOLDUC, B., ALBERTI, A., ARDYNA, M., ARKHIPOVA, K., CARMICHAEL, M., CRUAUD, C., DIMIER, C., DOMÍNGUEZ-HUERTA, G., FERLAND, J., KANDELS, S., LIU, Y., MAREC, C., PESANT, S., PICHERAL, M., PISAREV, S., POULAIN, J., TREMBLAY, J.-É., VIK, D., BABIN, M., BOWLER, C., CULLEY, A.I., DE VARGAS, C., DUTILH, B.E., IUDICONE, D., KARP-BOSS, L., ROUX, S., SUNAGAWA, S., WINCKER, P., SULLIVAN, M.B., ACINAS, S.G., BABIN, M., BORK, P., BOSS, E., BOWLER, C., COCHRANE, G., DE VARGAS, C., FOLLOWS, M., GORSKY, G., GRIMSLEY, N., GUIDI, L., HINGAMP, P., IUDICONE, D., JAILLON, O., KANDELS-LEWIS, S., KARP-BOSS, L., KARSENTI, E., NOT, F., OGATA, H., PESANT, S., POULTON, N., RAES, J., SARDET, C., SPEICH, S., STEMMANN, L., SULLIVAN, M.B., SUNAGAWA, S. and WINCKER, P. Marine DNA viral macro- and microdiversity from pole to pole. Cell, 2019, 177(5), 1109-1123. http://dx.doi. org/10.1016/j.cell.2019.03.040. PMid:31031001.

HALL JUNIOR, R.O. and MEYER, J.L. The trophic significance of bacteria in a detritus-based stream food web. Ecology, 1998, 79(6), 1995-2012. http:// dx.doi.org/10.1890/0012-9658(1998)079[1995:TT SOBI]2.0.CO;2.
HAMBLY, E. and SUTTLE, C.A. The viriosphere, diversity, and genetic exchange within phage communities. Current Opinion in Microbiology, 2005, 8(4), 444-450. http://dx.doi.org/10.1016/j. mib.2005.06.005. PMid:15979387.

JUNGER, P.C., AMADO, A.M., PARANHOS, R., CABRAL, A.S., JACQUES, S.M.S. and FARJALLA, V.F. Salinity drives the virioplankton abundance but not production in tropical coastal lagoons. Microbial Ecology, 2018, 75(1), 52-63. http://dx.doi. org/10.1007/s00248-017-1038-3. PMid:28721503.

JUNK, W.J., BAYLEY, P.B. and SPARKS, R.E. The flood pulse concept in river-floodplain systems. Canadian Special Publication of Fisheries and Aquatic Sciences, 1989, 106(1), 110-127.

KAVAGUTTI, V.S., ANDREI, A., MEHRSHAD, M., SALCHER, M.M. and GHAI, R. Phage-centric ecological interactions in aquatic ecosystems revealed through ultra-deep metagenomics. Microbiome, 2019, 7(1), 135. http://dx.doi.org/10.1186/s40168019-0752-0. PMid:31630686.

KNOWLES, B., SILVEIRA, C.B., BAILEY, B.A., BAROTT, K., CANTU, V.A., COBIÁN-GÜEMES, A.G., COUTINHO, F.H., DINSDALE, E.A., FELTS, B., FURBY, K.A., GEORGE, E.E., GREEN, K.T., GREGORACCI, G.B., HAAS, A.F., HAGGERTY, J.M., HESTER, E.R., HISAKAWA, N., KELLY, L.W., LIM, Y.W., LITTLE, M., LUQUE, A., MCDOLE-SOMERA, T., MCNAIR, K., DE OLIVEIRA, L.S., QUISTAD, S.D., ROBINETT, N.L., SALA, E., SALAMON, P., SANCHEZ, S.E., SANDIN, S., SILVA, G.G.Z., SMITH, J., SULLIVAN, C., THOMPSON, C., VERMEIJ, M.J.A., YOULE, M., YOUNG, C., ZGLICZYNSKI, B., BRAINARD, R., EDWARDS, R.A., NULTON, J., THOMPSON, F. and ROHWER, F. Lytic to temperate switching of viral communities. Nature, 2016, 531(7595), 466-470. http://dx.doi.org/10.1038/nature17193. PMid:26982729.

KOONIN, E.V. and WOLF, Y.I. Genomics of bacteria and archaea: the emerging dynamic view of the prokaryotic world. Nucleic Acids Research, 2008, 36(21), 6688-6719. http://dx.doi.org/10.1093/nar/ gkn668. PMid:18948295.

MELO, M.L., BERTILSSON, S., AMARAL, J.H.F., BARBOSA, P.M., FORSBERG, B.R. and SARMENTO, H. Flood pulse regulation of bacterioplankton community composition in an Amazonian floodplain lake. Freshwater Biology, 2019, 64(1), 108-120. http://dx.doi.org/10.1111/ fwb. 13198.

MELO, R.C.N. Células \& microscopia: principios e práticas. 2. ed. Barueri: Manole, 2018, 300 p.

PRADEEP RAM, A.S., CHAIBI-SLOUMA, S., KESHRI, J., COLOMBET, J. and SIME-NGANDO, T. Functional responses of bacterioplankton diversity 
and metabolism to experimental bottom-up and top-down forcings. Microbial Ecology, 2016, 72(2), 347-358. http://dx.doi.org/10.1007/s00248-0160782-0. PMid:27179523.

SILVA, B.S.D.O., COUTINHO, F.H., GREGORACCI, G.B., LEOMIL, L., DE OLIVEIRA, L.S., FRÓES, A., TSCHOEKE, D., SOARES, A.C., CABRAL, A.S., WARD, N.D., RICHEY, J.E., KRUSCHE, A.V., YAGER, P.L., DE REZENDE, C.E., THOMPSON, C.C. and THOMPSON, F.L. Virioplankton assemblage structure in the lower river and ocean continuum of the Amazon. MSphere, 2017, 2(5), e00366-e17. http://dx.doi.org/10.1128/ mSphere.00366-17. PMid:28989970.

SIME-NGANDO, T. Environmental bacteriophages: viruses of microbes in aquatic ecosystems. Frontiers in Microbiology, 2014, 5, 355. http://dx.doi. org/10.3389/fmicb.2014.00355. PMid:25104950.

SUTTLE, C.A. Viruses in the sea. Nature, 2005, 437(7057), 356-361. http://dx.doi.org/10.1038/ nature04160. PMid:16163346.
THINGSTAD, T.F. and LIGNELL, R. Theoretical models for the control of bacterial growth rate, abundance, diversity and carbon demand. Aquatic Microbial Ecology, 1997, 13(1), 19-27. http://dx.doi. org/10.3354/ame013019.

WeINBAUER, M.G. and SUTTLE, C.A. Potential significance of lysogeny to bacteriophage production and bacterial mortality in coastal waters of the Gulf of Mexico. Applied and Environmental Microbiology, 1996, 62(12), 4374-4380. http:// dx.doi.org/10.1128/AEM.62.12.4374-4380.1996. PMid: 16535459 .

WILLEY,J.M., SHERWOOD, L. and WOOLVERTON, C.J. Prescott's microbiology. 9th ed. New York: McGraw Hill, 2014.

Received: 04 May 2020 Accepted: 07 August 2020

Associate Editors: André Megali Amado Joyce Andreia dos Santos, Simone Jaqueline Cardoso. 